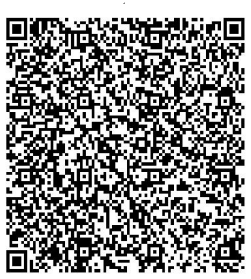

\title{
FOOD AND BEVERAGE FACILITIES - AN APPRAISAL OF SELECTED RESTAURANTS OF HARYANA TOURISM RESORTS
}

\section{Vinti Davar* \& Sandeep Malik**}

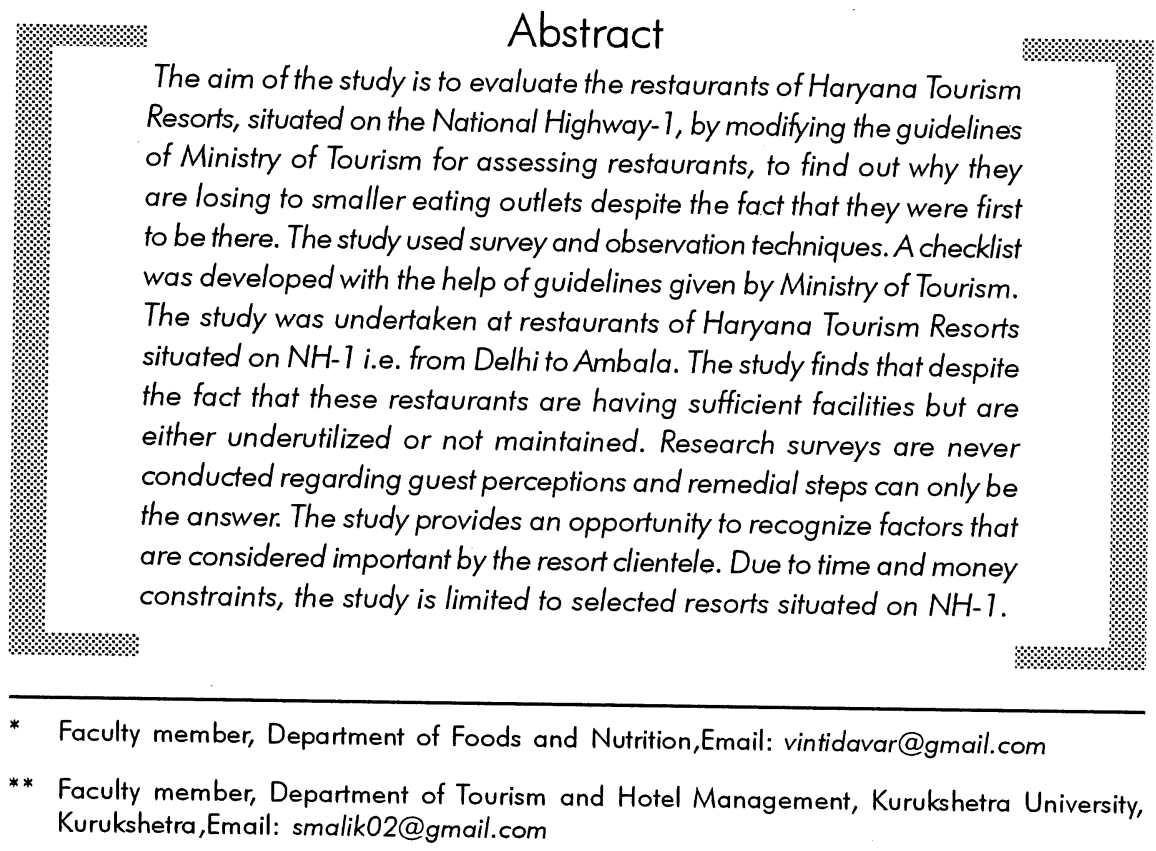




\section{Introduction}

India is a multi-destination country with a variety of tourist attractions and facilities. It hosts a number of wildlife parks, bird sanctuaries, museums and hundreds of historical monuments. All in all, India has in abundance what a tourist desires.

The dramatic growth of tourism over the last 50 years is one of the most remarkable economic and social phenomenon of the period worldwide. This phenomenal growth can be attributed to the social factors that enhance demand, the technology, which has made traveling easier and more economical; and the improved information technology, which has transformed the selling strategy of tourism. In India tourism sector is second largest net foreign exchange earner by way of invisible exports and it creates more jobs than any other sector for every rupee invested. It is the sector that integrates a wide range of economic activities having a major role in promoting large-scale employment opportunities.

Haryana pioneered into the field of tourism with the launching of its concept of highway tourism. Highways have varied embedded connotations, like the backbone of modern economy, the philosophy of life signifying the 'voyage unremitting' from birth till death, the history of mankind and its endeavor, the passion for speed and dart non-episodically etc. Making the best of the presence of national highways that crossed through it, Haryana Tourism decided to cater to the highway traveler. Next, it set up tourist complexes on the national highways. It also developed destination stations around Delhi-the National Capital and began to identify places of tourist interest in the State where tourism facilities could be developed.

While dotting the history of Haryana Tourism, the seventies saw the initial establishment of the tourism strategy and infrastructure, the eighties saw Haryana Tourism concentrated on promoting cultural and pilgrim tourism. The nineties brought in Adventure and Golf Tourism. The turn of the century is seeing Haryana Tourism venturing into privatization, village tourism, and development of new locations and the opening of crafts centres. Beginning with one resort in 1966, today Haryana Tourism runs 44 tourist complexes dotted all over the State. The resorts provide a wide range of tourist facilities such as restaurants, bars, fast food centres, health clubs, conference halls and recreational facilities like lakes for boating, picnic hides and children's parks. In all, 777 guest rooms are available in the resorts run by Haryana Tourism.

In fact, tourism in Haryana started by the public sector initiative as there was not much private investment in the tourism sector, to start with. Tourism policy of the government states that the state does not have much to offer as far as the natural 
resources are concerned, thus destinations would be developed focused on religious, leisure, culture and heritage and rural tourism along with continued emphasis on highway tourism. Despite these, Haryana has many advantages:

- Unity in diversity; more than 36 communities living side by side

- Good infrastructure

- Good law and order resulting in conducive environment

- Number of important pilgrimage sites

- Rich cultural tradition and heritage.

Idea behind this concept of highway tourism was to take full advantage of Haryana's proximity to Delhi and to build tourist complexes at strategic points along the highways passing through the state. According to a PHDCCl paper on Haryana, today the state has one of the best way-side amenities and highway motels. Haryana's share in domestic and international tourists stands at $2.4 \%$ and $2 \%$ respectively. (Intra Brand Equity foundation, Cll, 2005).

The highway, $\mathrm{NH}-1$, we have selected for study is life line for, Punjab, Haryana, J\&K Himachal, and Chandigarh. Perhaps, some of these are the most affluent states in the country. Also J\&K and Himachal are the main tourist destinations especially for North India. The highway also serves as the gateway to Delhi \& NCR region, the main employment center. There are 6 resorts of Haryana Tourism between Delhi and Ambala and we have selected the restaurants of these resorts for this study i.e. Ethnic India, Blue Jay, Skylark, Karna Lake, Parakeet and Kingfisher.

These resorts cater to the needs of local populace and mainly of highway travelers. Food remains basic need and attraction for visitors and profit center for management because the revenue from sale of food and beverage is greater than revenue from any other facility in these resorts. As Hubsch (1966) pointed out that hotel occupancies slid from 95 per cent in 1946 to 65 per cent in 1966. This led to identification of food and beverage as a potential source of profits. He further added that a hotel's food and beverage facilities can have a significant effect upon guestroom occupancy. The guests prefer a hotel with a good specialty restaurant, a swimming pool, and other amenities that make for an enjoyable stay. In continuation Bjorn Hanson (1984) found that no doubt F\&B operations are generally considered an integral part of hotels but hotel restaurants profitability is always a big challenge.

Eating habits of the clientele affect the margins. Highway travelers prefer to eat quick and small meals. This is supported by Thomas Baver et al (1993) that Asians prefer smaller but frequent meals, which mean a very high use of coffee shops and 
bistros. The fact that coffee shops are a cheaper form of dining would also be an element in influencing their high usage. Though travelers look for economical meals but quality and hygiene are always the main concerns. Auty (1992) studied criteria for selecting a restaurant by respondents. She found that restaurant type influenced the order of choice criteria. Only 4 restaurants out of 22 were chosen more for image than value for money and food type and food quality generally always ranked higher than image and atmosphere. Further, Clark and Wood (1998) asked respondents to rate ten aspects of their preferred restaurant on a five point scale. The most significant of these values is 'quality of food'. In general, there is indicative evidence from all the studies to suggest that there are relatively concrete factors such as range of food, quality of food, price of food, atmosphere and speed of service that are important in travelers choice of restaurants.

\section{Methodology}

The study is based on primary data collected by the researchers through survey and observation methods. For this purpose the restaurants of Haryana Tourism Resorts, situated on $\mathrm{NH}^{-1}$ (from Delhi to Ambala) were selected i.e. 6 in number. We modified the guidelines given by Ministry of Tourism, Govt. of India to be used as the parameter for evaluation. This questionnaire includes Location; Décor; Variety of Cuisines served; Senvice; Crockery and Cutlery; Kitchen Hygiene; Hygienic washing and drying of utensils, crockery and cutlery; Smart and clean uniform; Facilities for physically challenged people; Potable water and Parking facilities. The study period was from May 2007 to May 2008. The study used a Likert scale of 0 to 6, where 6 represent Excellent and 1 represents Highly Unsatisfactory.

\section{Results and Discussion}

While traveling we all look for mainly two things on the route besides stay:

- Good, clean food and beverages

- Public conveniences

According to Shenoy (2005) food is an integral aspect of tourist experience and nearly all tourists eat and dine out when traveling. In the old bygone days travelers used to carry home cooked packed food. Sometimes the food did not last long or got spoiled and also due to increase in discretionary income, lack of time to cook, save the labour of toiling in kitchen over hot burner and clean up afterwards, intention of being served, and above all exploration of food that we cannot cook at home, wayside eateries came up. 
Vivid eating places exist on National Highway-1 between Delhi and Ambala. People choose a restaurant based upon their dining experience that they expect, and it is up to the restaurant to exceed their expectations. Even if the service and ambience is friendly and warm, and the menu is remarkable, if the food really fails to meet or exceed their expectations, would they ever make an attempt to go back and try it again?

Everything that the restaurateur does within the confines of a great restaurant revolves around the taste, hygiene and presentation of food. This study indicated that despite the fact that Haryana Resorts are most beautifully and well located; with spacious parking; excellent seating; these failed to be popular among tourists and travelers as much as the private eateries including even small dhabhas. The ambience and service enhance the eating experience. It was explored that the fixtures, furniture, and almost all of the equipment were not fully exploited and maintained. The culinary choices offered are very limited, as shown in Table, and the ones listed on menu are most of the times not available. Mooney (1994) instituted that most important tangible element guiding the meal experience is the menu. He further added that in reality more often than not the menu also serves as a limit on what a food service operation is willing and able to prepare and serve.

Table: Evaluation of facilities in selected restaurants.

\begin{tabular}{|c|c|c|c|c|c|c|}
\hline & & & & & & $\mathrm{N}=6$ \\
\hline & Excellent & $\begin{array}{l}\text { Very } \\
\text { Good }\end{array}$ & Good & $\begin{array}{c}\text { Satis- } \\
\text { factory }\end{array}$ & $\begin{array}{l}\text { Unsatis- } \\
\text { factory }\end{array}$ & $\begin{array}{l}\text { Highly } \\
\text { unsatis- } \\
\text { factory }\end{array}$ \\
\hline Location & 6 & & & & & \\
\hline Décor & & & 3 & 3 & & \\
\hline Variety of cuisines served & & & & 2 & 4 & \\
\hline Service & & & & 2 & 2 & 2 \\
\hline Crockery & & & & 1 & 4 & 1 \\
\hline Kitchen Hygiene & & & & & 4 & 2 \\
\hline $\begin{array}{l}\text { Hygienic washing and drying } \\
\text { of utensils, crockery \& cutlery }\end{array}$ & & & & & 4 & 2 \\
\hline Uniform (smart and clean) & & & 2 & 4 & & \\
\hline $\begin{array}{l}\text { Facilities for physically } \\
\text { challenged }\end{array}$ & & & & & 1 & 5 \\
\hline Potable water & & & 2 & 3 & 1 & \\
\hline Parking facilities & 6 & & & & & \\
\hline
\end{tabular}

(List of facilities modified from guidelines of Ministry of Tourism, Govt. of India) 
The menu of all restaurants of Haryana Tourism is structured by head office, without consulting the experts and considering the essentialities of menu compiling. Davar and Davar (1998) in their study also illustrate that menu planning is done by the Head office of the Haryana Tourism Corporation and local executive chef; F \& B manger has no role in it. As Bhandari (1998) opines that art of compiling menu is not an easy job as people think it to be. A good menu can only be structured by $F \& B$ Manager and Executive Chef together in conjunction with sales department of the hotel unit. He further elaborates psychological factors, gastronomical factors and economical factors as three main factors responsible for effective menu planning. It is imperative to undertake consumer choice research from time to time to exceed customer demands. In line, Cattet and Smith (1994) pointed that the description of menu items seems to be an area of growing importance and research among certain restaurateurs.

Even the floor coverings and wall treatments reflect the culinary direction, as do the flatware, glassware, linens, uniforms, menus, graphics, lighting, and yes, even front-of-the-house personnel. The floor coverings were found to be old, unclean in two restaurants. The service staff was not well trained and lack courtesy. It has also been emphasized by Davar and Davar (1998) that kitchen is not fully equipped with modern facilities while the kitchen staff is claimed to be competent to make use of equipment provided. The food is cooked by experienced cooks who are not trained and have no formal education. "Head Cook" and /or "manager cum accountant" checks the quality of prepared food (taste, flavor etc.) and no expert tasting panel has been appointed.

The flatware and glassware were seen to be chipped and unclean. There are no facilities for physically challenged visitors except in only one resort restaurant. Astonishingly, the poorest of all factors was the kitchen hygiene. Food was seen lying uncovered in dirty utensils; the food waste and garbage unattended. Anon (1997) suggested that good hygienic conditions within restaurants will enhance the satisfaction level of customers and consequently customer's turnover will increase considerably. Also, Harris and West (1995) recommended that diners are more concerned with hygiene than anything else in a restaurant. Among the first things guests look for in restaurants are clean crockery, cutleny and glassware, presentable staff, clean lavatories and no flies. The results of the study are substantiated by Jennifer (1998) who undertook similar kind of study and reported that all caterers must provide clean, safe food for their customers and ensuring a good standard of hygiene is an essential part of their service. She further reported that hotel managers identified poor building design, insufficient staff to do the work and staff turnover 
as the three most important problems when trying to maintain high standards of cleanliness and hygiene.

There are no quality standards for storage, and storage space and equipment are under utilized. The facility for portable water in the form of water filter/RO though were found to be available but the guests do not rely and usually ask for bottled water.

The restaurants are not doing good business because they are not watching and keeping pace with the competition around them. Auty (1992) has rightly pointed out that the restaurateurs make small changes in their manner from time to time of their own rather than taking note of the competition in the area. If their style did not suit a regular set of diners they went out of business rather than making dramatic changes.

The corrective measures which can be adopted by higher management to improve upon the quality and sales of the food and beverages by these restaurants are: addition of menu items in line with the guest demands, seasonal changes in the menu, frequent training of staff, implementation of a formal system of quality control such as HACCP, supervision and spot checks.

\section{Bibliography}

- Anon, Diners Focusing on Hygiene, Caterer and Hotelkeeper, 5 June1997, p. 12.

- Anon, Dining by Numbers, Caterer and Hotelkeeper, 26 March 1998; pp. 60-62.

- Anon, Word of Mouth Sells Covers, Caterer and Hotelkeeper, 30 April, 1992, p.14.

- Auty, S., Consumer Choice and Segmentation in the Restaurant Industry, The Service Industries Journal, 12(3), 1992, pp. 324-339.

- Auty, S., Consumer Choice and Segmentation in the Restaurant Industry, The Service Industry's Journal, 12(3), 1992, pp. 324-339.

- Bhandari and Ravi G., The Art of Menu Compiling, International Journal of Management and Tourism, 1998, pp.139-140.

- Bjorn Hanson's, Hotel Food Services: Where's the Profit? Hotel Food and Beverage Management, the Cornell Hotel and Restaurant Administration Quarterly, August, 1984, pp. 187-191.

- Cattet, A. and Smith, C., The Menu as a Marketing Tool, in C.P. Cooper and A. Lockwood (Eds) Progress in Tourism, Recreation and Hospitality Management, Volume 6, Chi Chester: John Wiley and Sons Inc, 1994, pp. 149-163. 
- Clark, M.A. and Wood, R.C., Consumer Loyalty in the Restaurant Industry: A Preliminary Exploration of the Issues, International Journal of Contemporary Hospitality Management, 1998, 10(4): pp. 139-144.

- Coleman Philip, Griffith Chris, Botterill David: Welsh Caterers: An Exploratory Study of Attitudes Towards Safe Food Handling in the Hospitality Industry, Hospitality Management 19, 2000, pp. 145-157.

- Coleman, P., Griffith, C., Food Safety Legislation, Risk and the Caterer, Hygiene and Nutrition in Foodservice and Catering 1(4),1997, pp. 231-244

- Conway, H., Training Alert on Top Job Shortfall, Caterer and Hotelkeeper, 26th September, 1996, p. 7.

- Davar, Vinti \& Davar S.C. - Management of Food Services, A Study of Tourist Complex Owned and Controlled by Haryana Tourism Corporation, International Journal of Management and Tourism, 1998, pp. 43-47.

- Fleming's Study: Spreading the Buttery, Caterer and Hotelkeeper, p. 8.

- Harris, K.J.and West, J. J., Senior Savvy: Mature Diners' Restaurant Service Expectations, FIU Hospitality Review, 1995,13(2): pp. 35-44.

- Hubsch Allen W., Hotel Food and Beverage Management, The Cornell Hotel and Restaurant Administration Quarterly, Nov.1966, pp. 183-187.

- Jennifer A. Wade - Hygiene for Caterers - the Perennial Problem, Int. J. of Hospitality Management, 17, 1998, pp 83-87.

- Mooney, S., Jones, P. and Merricks, P., Planning and Developing the Menu, The Management of Food Service Operations, London: Cassell, 1994, pp. 45-58.

- Thomas Baver et al, The Changing Demand for Hotel Facilities in the Asia Pacific Region. Int. J. Hospitality Management, 1993 Vol. 12, No. 12, pp. 313-322.

- Warde, A. and Martens, L. Eating Out and the Commercialization of Mental Life, British Food Journal, 100(3); 1980, pp. 147-153. 